\title{
Determination of lithium bioretention by maize under hydroponic conditions
}

\author{
Jacek Antonkiewicz*, Czesława Jasiewicz, Małgorzata Koncewicz-Baran, \\ Renata Bączek-Kwinta
}

University of Agriculture in Krakow, Poland

*Corresponding author's e-mail: rrantonk@cyf-kr.edu.pl

Keywords: Lithium, hydroponics, tolerance index, content, translocation factor, bioaccumulation factor.

\begin{abstract}
Irrigation of cultivated plants can be a source of toxic lithium to plants. The data on the effect of lithium uptake on plants are scant, that is why a research was undertaken with the aim to determine maize ability to bioaccumulate lithium. The research was carried out under hydroponic conditions. The experimental design comprised 10 concentrations in solution differing with lithium concentrations in the aqueous solution (ranging from 0.0 to $256.0 \mathrm{mg} \mathrm{Li} \cdot \mathrm{dm}^{-3}$ of the nutrient solution). The parameters based on which lithium bioretention by maize was determined were: the yield, lithium concentration in various plant parts, uptake and utilization of this element, tolerance index (TI) and translocation factor (TF), metal concentrations in the above-ground parts index (CI) and bioaccumulation factor (BAF). Depression in yielding of maize occurred only at the highest concentrations of lithium. Lithium concentration was the highest in the roots, lower in the stems and leaves, and the lowest in the inflorescences. The values of tolerance index and $\mathrm{EC}_{50}$ indicated that roots were the most resistant organs to lithium toxicity. The values of translocation factor were indicative of intensive export of lithium from the roots mostly to the stems. The higher uptake of lithium by the above-ground parts than by the roots, which primarily results from the higher yield of these parts of the plants, supports the idea of using maize for lithium phytoremediation.
\end{abstract}

\section{Introduction}

The use of water for irrigation of plants can be a source of lithium toxicity to cultivated plants (Bradford 1963, Bingham et al. 1964). In the scientific literature, there is little information about phytotoxicity of lithium and its uptake and accumulation in the plant biomass. The role of lithium in plants has not been determined yet, although it is believed that it has certain metabolic functions in halophytes (Hawrylak-Nowak et al. 2012, Franzaring et al. 2016). In soil, easily soluble forms of lithium can constitute no more than $5 \%$ of its total content and can have a significant impact on the concentration in underground waters (Kabata-Pendias and Pendias 1999). In general, lithium occurs in all waters in the ionic form $\left(\mathrm{Li}^{+}\right)$. Some lithium salts are easily soluble, and owing to that lithium is taken up by plants proportionally to its concentration in the substratum (Aral and Vecchio-Sadus 2008). There are substantial differences amongst plant families, and even species in terms of their ability to uptake lithium and tolerance to its elevated concentration (Szentmihalyi et al. 1985, Kabata-Pendias and Mukherjee 2007). The uptake and distribution of lithium in plants are similar to those of potassium, but other proportions in its distribution can also be observed. In general, lithium is accumulated in larger amounts in leaves or other above-ground parts of plants, as compared with roots (Jurkowska et al. 1998, 2003). Numerous studies have shown that the defence response of plants to toxic concentrations of metals consists in, among other things, deposition of these metals in cell walls and retention of elements in roots, or an increase in enzymatic activity in plant leaves (Kayihan et al. 2012, Lu et al. 2010). Owing to its chemical nature, lithium, despite being a cation, is not subject to complexing in cell walls (Léonard et al. 1995, Lintschinger et al. 1997). Lithium is a mobile element that translocates easily from roots to the above-ground parts (Jurkowska and Rogóż 1991).

Plants from the Solanaceae family are resistant to high lithium concentrations; in salty soils they can contain more than $1,000 \mathrm{mg} \mathrm{Li} \cdot \mathrm{kg}^{-1}$. Lithium toxicity is manifested mainly by chlorosis, necrotic spots on leaves, and damages on roots (Bingham et al. 1964). Research conducted by Allender et al. (1997) confirms that small concentrations of lithium have an effect on plant growth. The stimulating effect of small concentrations of metals, including lithium, on processes like growth, flowering or germination is called 'hormesis' (Forbes 2000). Plant cells have mechanisms which maintain a proper level of lithium ions in their various compartments (Allender et al. 1997, Calabrese and Baldwin 2003). In addition, research conducted by Garzon and Flores (2013) confirms that sublethal concentrations of herbicides, metals, including lithium, stimulate the growth of cultivated plants.

Lithum brines (Shacklette and Boerngen 1984), as well as the wide use of lithium in various fields of industry and waste 
management e.g. battery disposal, use of biosloids, aluminum processing, glass and ceramic production (Enghag 2008, Al-Thyabat et al. 2013, Hull et al. 2014,) raises the question to what extent this will lead to environmental pollution. High lithium concentration in solutions can be toxic to plants (Bradford 1963). At a concentration of 50-100 $\mu \mathrm{g} \cdot \mathrm{dm}^{-3}$ in waters used for field irrigation, lithium may have an effect on the chemical composition of plants, disturbing the uptake of elements indispensable for plant growth and development (Kabata-Pendias and Mukherjee 2007).

In recent years, tolerance index (TI) has been considered the most reliable factor in determining the toxicity of metals to plants (Murphy and Tayz 1995, Audet and Charest 2007). Translocation factor is a parameter that determines the relationship between lithium concentration in the above-ground parts and the concentration of this element in the roots (Marchiol et al. 2004). Bioaccumulation factor is another indicator that determines the relationship between lithium concentration in plants and the concentration of this element in the nutrient solution (Ruus et al. 2005, Mackay and Fraser 2000).

That is why there is a potential risk of increasing the content of this element in human and animal diet, without any signs of it being harmful to plants (Kabata-Pendias and Mukherjee 2007). Hence, the aim of the undertaken research was to determine the lithium bioretention ability of maize (as an indicator plant, which is of wide use in food and feedstuff production), and to determine lithium toxicity to this species. The conducted experiment was also designed to reflect the real bioaccumulation of lithium by maize.

Determination of lithium bioretention by maize was carried out under hydroponic conditions because of the possibility of controlling the impact of the metal on the tested plant.

In aquaculture conditions, in contrast to the pot experiment, we may regulate the availability of the elements for the plants, use different nutrient solutions, mineral salts and control the uptake of an element by the plant. The experiments in hydroponic conditions are the most useful to assess the impact of an element on plants, due to the possibility of eliminating other factors that affect the uptake processes. Therefore, studies were carried out on lithium bioretention in hydroponic conditions.

\section{Materials and methods}

The research on determining the lithium bioretention ability of maize was carried out under hydroponic conditions.

\section{Experimental design}

Seeds of maize (Zea mays L., family: Poaceae), 'KB-270’ c.v., untreated, were used. The experiment comprised ten lithium concentrations in solution (each in four replications): the control and nine levels of lithium concentration in the nutrient solution (Table 1).

\section{Seedling preparation}

Once the seeds germinated in crystallizing dishes, they were sown into the plastic trays filled with the river sand. To eliminate chemical and microbiological threats, prior to sowing, the sand was washed with hydrochloric acid (20\%) and rinsed several times with the tap water, and then with the distilled water. Seed planting into the substratum prepared this way aimed to obtain the seedlings with low lithium concentration and microbiologically pure. Moisture content of the substratum during seedling preparation was maintained at the level of $50 \%$ of the maximum water capacity. Water losses were supplemented with redistilled water.

When the plants reached the appropriate size (the $3^{\text {rd }}$ leaf stage), they were moved to a growing container filled with $25 \mathrm{dm}^{3}$ of clean redistilled water, to enable their adaptation to water conditions. Sixteen plants were placed in each growing container. The seedlings were taken out of the substratum under a stream of redistilled water, so as not to damage the root system.

\section{Experimental conditions}

On the third day after placing the plants into the growing containers, the Hoagland nutrient solution was added. It contained macro- and microelements (in $\mathrm{mg} \cdot \mathrm{dm}^{-3}$ ) necessary for the plant growth and development: $\mathrm{Ca}\left(\mathrm{NO}_{3}\right)_{2} \cdot 4 \mathrm{H}_{2} \mathrm{O}$ $-240.0 ; \mathrm{KNO}_{3}-10.0 ; \mathrm{KH}_{2} \mathrm{PO}_{4}-7.0 ; \mathrm{KCl}-4.0 ; \mathrm{MgSO}_{4} \cdot 7 \mathrm{H}_{2} \mathrm{O}$ $-100.0, \mathrm{FeSO}_{4} \cdot 7 \mathrm{H}_{2} \mathrm{O}, \mathrm{CuSO}_{4} \cdot 5 \mathrm{H}_{2} \mathrm{O}-0.05 ; \mathrm{H}_{3} \mathrm{BO}_{3}-0.12$; $\mathrm{MnSO}_{4} \cdot \mathrm{H}_{2} \mathrm{O}-0.25 ; \mathrm{ZnSO}_{4} \cdot 7 \mathrm{H}_{2} \mathrm{O}-0.10 ; \mathrm{Na}_{2} \mathrm{MoO}_{4} \cdot 2 \mathrm{H}_{2} \mathrm{O}$ - 0.10 (Hoagland and Arnon 1950). During the experiment,

Table 1. Experimental design

\begin{tabular}{|c|c|c|c|}
\hline \multirow[b]{2}{*}{ Doses } & \multicolumn{3}{|c|}{ Li dose } \\
\hline & $\begin{array}{c}\mathrm{mg} \mathrm{Li} \cdot \mathrm{dm}^{-3} \\
\text { nutrient solution }\end{array}$ & $\begin{array}{c}\mathrm{mmol} \mathrm{Li} \cdot \mathrm{dm}^{-3} \\
\text { nutrient solution }\end{array}$ & $\begin{array}{l}\mathrm{mg} \mathrm{Li} \cdot \text { growing } \\
\text { container }^{-1}\end{array}$ \\
\hline D1 & 0.0 & 0.0000 & 0 \\
\hline D2 & 1.0 & 0.0085 & 25 \\
\hline D3 & 2.0 & 0.0425 & 50 \\
\hline D4 & 4.0 & 0.0850 & 100 \\
\hline D5 & 8.0 & 0.1275 & 200 \\
\hline D6 & 16.0 & 0.1360 & 400 \\
\hline D7 & 32.0 & 0.1445 & 800 \\
\hline D8 & 64.0 & 0.1530 & 1,600 \\
\hline D9 & 128.0 & 0.1615 & 3,200 \\
\hline D10 & 256.0 & 0.1700 & 6,400 \\
\hline
\end{tabular}


the solution containing NPK + microelements was replenished about every 10 days and iron was replenished every 4 days. The level of the liquid in the containers was constantly checked and the solution was constantly aerated using an air pump.

Four weeks after seedling removal to the growing containers, when the plants developed typical aquatic root systems, lithium was added to the nutrient solution as water soluble salt $-\mathrm{LiCl}$ - $\mathrm{H}_{2} \mathrm{O}$, in concentrations of 1.0 to $256.0 \mathrm{mg} \mathrm{Li} \cdot \mathrm{dm}^{-3}$ of the solution (Table 1). The plants were harvested after two months of the experiment, when male inflorescences (panicle) appeared. During the harvest, the above-ground parts of maize were segregated into leaves of particular layers of the plant, stems and inflorescences. Special attention was paid to rinsing the roots several times with redistilled water. The aim of this procedure was to rinse out lithium held on the outer surface of roots.

The plant material was dried in a forced air circulation dryer at $105^{\circ} \mathrm{C}$, and the yield of dry matter of individual plant parts was determined. The dried biomass was crushed in a laboratory mill to prepare it for chemical analyses. After the sample ashing in a chamber furnace $\left(550^{\circ} \mathrm{C}\right.$ for $\left.5 \mathrm{~h}\right)$ and dissolving the remains in diluted nitric acid $(1: 2, v / v)$, lithium concentration was determined using atomic absorption spectrophotometry method on Philips PU 9100X apparatus (Ostrowska et al. 1991, Kusznierewicz et al. 2012).

\section{Analytical quality control}

An internal reference plant material was analysed for quality assurance. Recoverable concentration was $92-108 \%$ of the estimated value.

\section{Computations and statistical analysis of the results}

For the obtained results, one-factor analysis of variance was conducted in a completely randomized design using F-Fisher test. The significance of differences between arithmetic means was verified on the basis of homogenous groups determined by Duncan test at the significance level $\alpha \leq 0.05$. All statistical computations and selected graphic presentations of the results were made using Statistica 10.0 software (Statsoft, USA).

The following parameters were assumed as the basis for determining lithium bioretention by maize:

1. Yield (Y);

2. Tolerance index (TI) - defined as the ratio of the yield (Y) of plants growing on the substratum polluted with lithium to the yield (Y) from the control objects, unpolluted with this element (Murphy and Tayz 1995);

3. Half maximal effective concentration $\left(\mathrm{EC}_{50}\right)-\mathrm{Li}$ concentration ( $\mathrm{mg} \mathrm{Li} \cdot \mathrm{dm}^{-3}$ nutrient solution) causing $50 \%$ inhibition of yield. To calculate $\mathrm{EC}_{50}$ values, concentration (log scale) - response (yield decrease in comparison to the control object - D1) curves were graphed using Excel. The $\mathrm{EC}_{50}$ of the curves was calculated by non-linear regression analysis and interpolation according to the method of Alexander et al. (1999). Statistical significance was accepted at a level $\alpha \leq 0.05$

4. Lithium concentration $(\mathrm{C})$ in individual plant parts - lithium concentration in the above-ground parts of maize was presented as a weighted mean (calculated by dividing the sum of the products of maize individual parts yields and lithium concentration in these parts and total maize yield);
5. Translocation factor (TF) - which is the ratio of lithium concentration in the above-ground parts to the concentration of this element in the roots (Marchiol et al. 2004);

6. Bioaccumulation factor (BAF) - computed as the ratio of lithium concentration in the whole plant to its concentration in the solution (Ruus et al. 2005, Mackay and Fraser 2000).

7. Lithium uptake (U) by maize was calculated as a product of dry matter yield (Y) and the concentration (C) of the element, according to the formula: $U=Y \cdot C$;

8. Utilization factor- defined as lithium utilization by maize and expressed as the share of lithium amount taken up by the plant (U) in the total amount of lithium supplied to the growing container.

\section{Results}

\section{Observations during the plants vegetation}

Compared to the plants exposed to concentrations 128.0 and $256.0 \mathrm{mg} \mathrm{Li} \cdot \mathrm{dm}^{-3}$, where plants were smaller and had thinner and shorter stems, the plants exposed to lower lithium concentrations in solution $\left(1.0-64.0 \mathrm{mg} \mathrm{Li} \cdot \mathrm{dm}^{-3}\right)$ were well developed, and had thick stems. The symptoms of lithium phytotoxicity were observed in plants at concentrations of 9 and 10 (D9-D10), i.e. at concentrations of 128.0 and $256.0 \mathrm{mg}$ $\mathrm{Li} \cdot \mathrm{dm}^{-3}$, respectively. In the case of the above-ground parts, the symptoms were chloroses, necroses and browning which usually resulted in leaf drying. In the case of roots, a change in the root colouring (brown colour) and growth inhibition were noticed. Due to the inhibition of the main root and lateral roots elongation, the morphology of root system changed, and the effect was more pronounced at the highest lithium concentrations in solution $\left(256.0 \mathrm{mg} \mathrm{Li} \cdot \mathrm{dm}^{-3}\right)$, (Phot. 1).

\section{Maize yield}

The yield was dependent on lithium concentration in the nutrient solution and on the index part of the plant. According to the data presented in Table 2, the effect of lithium was ambiguous.

An increase in lithium concentration ranging from 1 to $32 \mathrm{Li} \cdot \mathrm{dm}^{-3}$ (D2-D7) had a stimulating effect on total maize yield. In relation to the control object, the increase was from $8.3 \%$ (D2) to $17.2 \%$ (D7) in the case of the whole plants. The highest increase in total maize yield (about $22.3 \%$ in relation to the control object) was observed at concentration of $16 \mathrm{mg}$ $\mathrm{Li} \cdot \mathrm{dm}^{-3}$ (D6). The concentration of $64 \mathrm{mg} \mathrm{Li} \cdot \mathrm{dm}^{-3}$ (D8) decreased the total yield by about $4 \%$ in relation to the control. The concentrations in solution of 128 and $256 \mathrm{mg} \mathrm{Li} \cdot \mathrm{dm}^{-3}$ (D9 and D10) significantly decreased the yield by, respectively, more than $38 \%$ and $85 \%$ in relation to the control (Table 2 ).

The knowledge about the structure of the constituents of the yield of maize above-ground parts is important in the assessment of the lithium effect on crop yielding. The percentage share of the above-ground parts in total yield of maize varied, depending on the concentrations in solution, from $91 \%$ (D10) to $96 \%$ (D1), and for roots - from $4 \%$ (D1) to $9 \%$ (D10), respectively. The stems constituted the highest mean share in the yield of the above-ground parts $(68.1 \%)$, followed by leaves $(24.2 \%)$, roots $(5.4 \%)$, and male inflorescences $(2.3 \%)$.

According to the data presented in Table 2, the effect of various lithium concentrations in solution on the index parts 
of maize was ambiguous. A stimulating effect of lithium on the yield of stems and leaves was observed until the level of $32 \mathrm{mg} \mathrm{Li} \cdot \mathrm{dm}^{-3}$ of the nutrient solution (D7). In the case of roots, a stimulating effect was observed until the level of $64 \mathrm{mg} \mathrm{Li} \cdot \mathrm{dm}^{-3}$ of the nutrient solution (D8), yet that level was statistically insignificant. In the case of inflorescences, a concentration in solution of $4 \mathrm{mg} \mathrm{Li} \cdot \mathrm{dm}^{-3}$ of the nutrient solution caused a significant depression in yielding of this part of the plant.

By analysing the yield of the above-ground parts (total yield of stems, leaves and inflorescences), a stimulating effect of lithium concentrations in solution on the increase in yield (which, in relation to the control, was from $7 \%$ to $16 \%$ ) was observed at concentrations from 1.0 to $32.0 \mathrm{mg} \mathrm{Li} \cdot \mathrm{dm}^{-3}$ (D2-D7). A more pronounced stimulating effect of lithium was observed in the case of roots. The increase in their yield, at lithium concentration ranging from 1 to $64 \mathrm{mg} \mathrm{Li} \cdot \mathrm{dm}^{-3}$ (D2-D8) was from $7 \%$ to $137 \%$ in relation to the control object. The concentrations in solution of $16 \mathrm{mg} \mathrm{Li} \cdot \mathrm{dm}^{-3}$ turned out to have the most stimulating effect on the growth of maize roots.
The greatest lithium toxicity was observed at a concentration of $256 \mathrm{mg} \mathrm{Li} \cdot \mathrm{dm}^{-3}$. At that concentration, stem yield was about $10 \%$, leaf yield $29 \%$, and root yield approximately $33 \%$ compared to the yield from the control. Even greater effects of lithium toxicity were observed in inflorescences, as at concentrations of 128 and $256 \mathrm{mg} \mathrm{Li} \cdot \mathrm{dm}^{-3}$ of the nutrient solution, maize did not develop these organs.

\section{Tolerance index and EC50 values}

An attempt was made to assess lithium toxicity based on tolerance index (TI) that was estimated as the ratio of yield obtained at lithium concentrations in solution 1.0-256.0 mg $\mathrm{Li} \cdot \mathrm{dm}^{-3}$ (D2-D10) to the yield obtained in the control (D1), (Table 3). Tolerance index may take values $\mathrm{TI}<1$, TI $=1$, $\mathrm{TI}>1$. If the index is less than one, it indicates plant growth inhibition, and sometimes total necrosis of plants. If the index equals one, it is indicative of no effect of pollution on yielding, and a value of the index higher than one indicates a positive effect of pollution on plant growth and development.

Table 2. Means of the biomass of individual parts of maize Zea mays $L$. plants $\left(\mathrm{g} \cdot \mathrm{growing}\right.$ container $\left.{ }^{-1}\right)$

\begin{tabular}{|c|c|c|c|c|c|c|}
\hline \multirow{2}{*}{ Doses } & \multicolumn{5}{|c|}{ Indicative plant parts } & \multirow{2}{*}{ Total } \\
\hline & Stems & Leaves & Inflorescences & Above ground parts total & Roots & \\
\hline D1 & $284 c^{*}$ & $80 \mathrm{bc}$ & $13.3 \mathrm{~b}$ & $377 \mathrm{bc}$ & $15.7 \mathrm{~d}$ & $393 \mathrm{~cd}$ \\
\hline D2 & $293 \mathrm{bc}$ & $95 \mathrm{~b}$ & $16.1 \mathrm{a}$ & $404 \mathrm{~b}$ & $21.9 \mathrm{~b}$ & $426 \mathrm{~b}$ \\
\hline D3 & 295 bc & $93 b$ & $15.9 \mathrm{a}$ & 404 & $21.7 b$ & $425 b$ \\
\hline D4 & 294 bc & $95 \mathrm{~b}$ & $10.7 \mathrm{c}$ & $400 \mathrm{~b}$ & $19.0 \mathrm{c}$ & $419 \mathrm{bc}$ \\
\hline D5 & 295 bc & $94 \mathrm{~b}$ & $8.0 \mathrm{~d}$ & $397 \mathrm{~b}$ & $18.5 \mathrm{c}$ & $415 \mathrm{bc}$ \\
\hline D6 & $315 a b$ & $116 a$ & $12.9 \mathrm{~b}$ & $443 a$ & $37.3 \mathrm{a}$ & $481 \mathrm{a}$ \\
\hline D7 & $333 a$ & $95 \mathrm{~b}$ & $10.8 \mathrm{c}$ & 439 a & $21.4 \mathrm{~b}$ & $461 \mathrm{a}$ \\
\hline D8 & $283 c$ & $70 \mathrm{~d}$ & $8.1 \mathrm{~d}$ & $361 \mathrm{c}$ & $16.8 \mathrm{~d}$ & $378 d$ \\
\hline D9 & $98 \mathrm{~d}$ & $44 \mathrm{e}$ & $0.0 \mathrm{e}$ & $143 d$ & $7.8 \mathrm{e}$ & $150 \mathrm{e}$ \\
\hline D10 & 30 e & $23 \mathrm{f}$ & $0.0 \mathrm{e}$ & 53 e & $5.1 \mathrm{f}$ & $58 \mathrm{f}$ \\
\hline
\end{tabular}

* Means followed by the same letters in columns did not differ significantly at $p<0.05$ according to the Duncan test

Table 3. The impact of lithium on maize Zea mays $L$. yield tolerance index $(\mathrm{TI})$ and $\mathrm{EC}_{50}$ values

\begin{tabular}{|c|c|c|c|c|c|c|}
\hline \multirow[b]{2}{*}{ Doses } & \multicolumn{5}{|c|}{ Indicative plant parts } & \multirow[b]{2}{*}{ Total } \\
\hline & Stems & Leaves & Inflorescences & $\begin{array}{l}\text { Above ground } \\
\text { parts total }\end{array}$ & Roots & \\
\hline D1 & - & - & - & - & - & - \\
\hline D2 & $1.03 \mathrm{bc}^{*}$ & $1.22 \mathrm{~b}$ & $1.22 \mathrm{a}$ & $1.07 \mathrm{~b}$ & $1.39 \mathrm{~b}$ & $1.09 \mathrm{~b}$ \\
\hline D3 & $1.04 \mathrm{bc}$ & $1.19 \mathrm{~b}$ & $1.20 \mathrm{a}$ & $1.07 \mathrm{~b}$ & $1.38 \mathrm{~b}$ & $1.09 \mathrm{~b}$ \\
\hline D4 & $1.04 \mathrm{bc}$ & $1.21 \mathrm{~b}$ & $0.81 \mathrm{c}$ & $1.06 \mathrm{~b}$ & $1.21 \mathrm{c}$ & $1.07 \mathrm{~b}$ \\
\hline D5 & $1.04 \mathrm{bc}$ & $1.20 \mathrm{~b}$ & $0.61 \mathrm{~d}$ & $1.05 \mathrm{~b}$ & $1.18 \mathrm{c}$ & $1.06 \mathrm{~b}$ \\
\hline D6 & $1.11 a b$ & $1.49 \mathrm{a}$ & $0.98 \mathrm{~b}$ & $1.17 \mathrm{a}$ & $2.38 \mathrm{a}$ & $1.23 \mathrm{a}$ \\
\hline D7 & $1.17 \mathrm{a}$ & $1.22 \mathrm{~b}$ & $0.82 \mathrm{c}$ & $1.16 \mathrm{a}$ & $1.36 \mathrm{~b}$ & $1.18 \mathrm{a}$ \\
\hline D8 & $1.00 \mathrm{c}$ & $0.90 \mathrm{c}$ & $0.61 \mathrm{~d}$ & $0.96 \mathrm{c}$ & $1.07 \mathrm{~d}$ & $0.97 \mathrm{c}$ \\
\hline D9 & $0.35 d$ & $0.57 \mathrm{~d}$ & $0.00 \mathrm{e}$ & $0.38 \mathrm{~d}$ & $0.50 \mathrm{e}$ & $0.38 \mathrm{~d}$ \\
\hline D10 & $0.11 \mathrm{e}$ & $0.30 \mathrm{e}$ & $0.00 \mathrm{e}$ & $0.14 \mathrm{e}$ & $0.32 \mathrm{f}$ & $0.15 \mathrm{e}$ \\
\hline $\begin{array}{l}\mathrm{EC}_{50} \\
\left(\mathrm{mg} \mathrm{Li} \cdot \mathrm{dm}^{-3}\right. \\
\text { nutrient solution) }\end{array}$ & 135 & 174 & 50 & 139 & 180 & 140 \\
\hline
\end{tabular}

* Means followed by the same letters in columns did not differ significantly at $p<0.05$ according to the Duncan test 
The values of tolerance index (TI) are presented separately for individual components of the yield of the above-ground parts and roots of maize (Table 3 ). Taking into account the values of tolerance index (TI), it was established that maize roots were more resistant to the toxic effect of lithium than the above-ground parts. In the case of roots, TI value less than one (0.50) was recorded at a concentration of $128 \mathrm{mg} \mathrm{Li}$ $\cdot \mathrm{dm}^{-3}$ (D9). In the case of above-ground parts, TI value less than one (0.96) was recorded at a concentration of $64 \mathrm{mg} \mathrm{Li}$ $\cdot \mathrm{dm}^{-3}$ (D8). The values of tolerance index $(0.32$ for roots and 0.1 for the above-ground parts) at a lithium concentration of $256 \mathrm{mg} \mathrm{Li} \cdot \mathrm{dm}^{-3}$ were the second evidence indicating higher sensitivity of maize above-ground parts to excessive amounts of lithium.

An assessment of lithium toxicity to the constituents of maize above-ground parts was also conducted. Based on the value of tolerance index, it was established that inflorescences were the most sensitive organs (0.81) since the depression in yielding occurred already at a lithium concentration of $4 \mathrm{mg}$ $\mathrm{Li} \cdot \mathrm{dm}^{-3}$ of the nutrient solution (D4). The calculated lithium concentration that results in a $50 \%$ reduction in the yield of maize inflorescences $\left(\mathrm{EC}_{50}\right)$ was $50 \mathrm{mg} \mathrm{Li} \cdot \mathrm{dm}^{-3}$. Leaves were also sensitive; the value of tolerance index less than one occurred at a concentration of $64 \mathrm{mg} \mathrm{Li} \cdot \mathrm{dm}^{-3}$ (D8). Stems were the most resistant as the value of tolerance index less than one occurred at a concentration of $128 \mathrm{mg} \mathrm{Li} \cdot \mathrm{dm}^{-3}$ (D9). The $\mathrm{EC}_{50}$ values for leaves and stems were, respectively, 174 and $135 \mathrm{mg} \mathrm{Li} \cdot \mathrm{dm}^{-3}$. The highest values of this parameter were calculated for roots $\left(180 \mathrm{mg} \mathrm{Li} \cdot \mathrm{dm}^{-3}\right)$.

\section{Lithium concentration in maize}

The lithium concentration in maize was dependent on the analysed part of the plant and on the concentration of this element in the nutrient solution (Table 4). When analysing the lithium concentration in the whole plant, a higher concentration of this element was observed in the roots than in the above-ground parts. In the individual plant parts the concentration of this element was the highest in the roots, lower in the stems and leaves, and the lowest in inflorescences (Table 4). A different pattern was observed at a concentration in solution of $256.0 \mathrm{mg} \mathrm{Li} \cdot \mathrm{dm}^{-3}$ (D10) at the highest lithium concentration in the nutrient solution. Contrary to the other objects, the stems had the highest lithium concentration, followed by roots, and the leaves had a lower lithium concentration.

The increase in lithium concentration in the nutrient solution was accompanied by an increase in the concentration of this element in individual index parts of maize. The control object (D1, without the addition of lithium) had a trace concentration of lithium, below the detection limit of the atomic absorption spectrophotometer used. At the highest lithium concentration $\left(256 \mathrm{mg} \mathrm{Li} \cdot \mathrm{dm}^{-3}, \mathrm{D} 10\right)$, the increase in the concentration of this element in stems, leaves and roots amounted to, respectively, over 376, 362 and 26-fold more compared to concentration in solution $1.0 \mathrm{mg} \mathrm{Li} \cdot \mathrm{dm}^{-3}(\mathrm{D} 2)$. Lithium concentration in maize inflorescence was analogous; the lowest (trace) lithium concentration was observed at $0.0-4.0 \mathrm{mg} \mathrm{Li} \cdot \mathrm{dm}^{-3}$. At higher concentrations (D5-D8), the increase in lithium concentration was accompanied by an increase in the concentration of this element in inflorescences, ranging from 3.98 to $99.77 \mathrm{mg} \mathrm{Li} \cdot \mathrm{kg}^{-1} \mathrm{DM}$. High concentration of lithium in solution (128 and $256 \mathrm{mg} \cdot \mathrm{dm}^{-3}$ ) prevented the formation of inflorescences (Table 2).

When analysing the topography of the concentration of lithium in individual index parts of maize, greater diversity in its concentration was noticed at lower lithium concentrations in the substratum $\left(1.0-8.0 \mathrm{mg} \mathrm{Li} \cdot \mathrm{dm}^{-3}\right)$ compared to the highest lithium concentration in the nutrient solution (128.0-256.0 $\left.\mathrm{mg} \mathrm{Li} \cdot \mathrm{dm}^{-3}\right)$.

\section{Lithium concentration in individual layers of maize leaves}

A certain pattern was observed in lithium distribution in leaves of individual layers. Its concentration in the oldest leaves increased gradually and was the highest in third-layer leaves, in comparison to the other layers (Figure 1). However, in the leaves from layers 4-9 it systematically declined, towards the youngest leaves (layer 9).

Lithium concentration in leaves from individual layers increased along with an increase in the concentration of this element in the nutrient solution. The concentration of $128 \mathrm{mg} \mathrm{Li} \cdot \mathrm{dm}^{-3}$ caused partial obliteration of differences between lithium concentration in leaves of individual layers. Maize leaves at a concentration $128.0 \mathrm{mg} \mathrm{Li} \cdot \mathrm{dm}^{-3}$ contained from 627.8 to $1,903.2 \mathrm{mg} \mathrm{Li} \cdot \mathrm{kg}^{-1} \mathrm{DM}$, and it was a few dozen times higher than in the 8 other objects (Figure 1). Lithium

Table 4. Lithium concentration in indicative parts of maize Zea mays L. ( $\mathrm{mg} \cdot \mathrm{kg}^{-1} \mathrm{~d} . \mathrm{m}$.)

\begin{tabular}{|l|c|c|c|c|c|c|}
\hline \multirow{2}{*}{ Doses } & \multicolumn{5}{|c|}{ Indicative plant parts } & \multirow{2}{*}{ Total } \\
\cline { 2 - 6 } & Stems & Leaves & Inflorescences & Above ground parts total & Roots & \\
\hline D1 & $0.00 \mathrm{~g}^{*}$ & $0.00 \mathrm{e}$ & $0.00 \mathrm{~d}$ & $0.00 \mathrm{f}$ & $0.00 \mathrm{j}$ & $0.0 \mathrm{~h}$ \\
\hline D2 & $7.85 \mathrm{~g}$ & $5.56 \mathrm{e}$ & $0.00 \mathrm{~d}$ & $7.01 \mathrm{f}$ & $92.7 \mathrm{i}$ & $11.4 \mathrm{~h}$ \\
\hline D3 & $20.1 \mathrm{fg}$ & $12.5 \mathrm{e}$ & $0.00 \mathrm{~d}$ & $17.6 \mathrm{f}$ & $178 \mathrm{~h}$ & $25.8 \mathrm{gh}$ \\
\hline D4 & $40.6 \mathrm{efg}$ & $27.2 \mathrm{e}$ & $0.00 \mathrm{~d}$ & $36.3 \mathrm{f}$ & $402 \mathrm{~g}$ & $52.9 \mathrm{~g}$ \\
\hline D5 & $99.1 \mathrm{ef}$ & $55.0 \mathrm{e}$ & $3.98 \mathrm{c}$ & $86.7 \mathrm{e}$ & $730 \mathrm{f}$ & $115 \mathrm{f}$ \\
\hline D6 & $114 \mathrm{e}$ & $111 \mathrm{e}$ & $3.44 \mathrm{c}$ & $110 \mathrm{e}$ & $1,211 \mathrm{e}$ & $195 \mathrm{e}$ \\
\hline D7 & $356 \mathrm{~d}$ & $408 \mathrm{~d}$ & $30.8 \mathrm{~b}$ & $359 \mathrm{~d}$ & $1,733 \mathrm{~g}$ & $423 \mathrm{~d}$ \\
\hline D8 & $939 \mathrm{c}$ & $870 \mathrm{c}$ & $99.8 \mathrm{a}$ & $908 \mathrm{c}$ & $1,979 \mathrm{c}$ & $956 \mathrm{c}$ \\
\hline D9 & $2,099 \mathrm{~b}$ & $1,769 \mathrm{~b}$ & & $1,998 \mathrm{~b}$ & $2,201 \mathrm{~b}$ & $2,008 \mathrm{~b}$ \\
\hline D10 & $2,963 \mathrm{a}$ & $2,019 \mathrm{a}$ & & $2,551 \mathrm{a}$ & $2,534 \mathrm{a}$ & $2,550 \mathrm{a}$ \\
\hline
\end{tabular}

${ }^{*}$ Means followed by the same letters in columns did not differ significantly at $p<0.05$ according to the Duncan test 
concentration of $256 \mathrm{mg} \mathrm{Li} \cdot \mathrm{dm}^{-3}$ in the nutrient solution (D10) made the analysis of individual layers impossible due to the very low yield.

\section{Lithium translocation factor (TF) and bioaccumulation factor (BAF) in maize}

Values of translocation factor higher than one indicate that a given metal has transferred in larger amounts to the above-ground parts than to roots.

The data presented in Table 5 indicate that the increase in lithium concentration in the nutrient solution was accompanied by its increased translocation, mostly to the stems, while to the least extent to the inflorescences. At the highest lithium concentration in the nutrient solution $\left(256 \mathrm{mg} \mathrm{Li} \cdot \mathrm{dm}^{-3}\right)$, the values of translocation factor in the above-ground parts and stems were higher than one, which is indicative of an intensive transfer of lithium from the roots to the above-ground parts and proves that lithium concentration in the roots was lower than in the above-ground parts and stems.

In our experiment, the increasing lithium concentrations had a significant effect on the increase in the value of lithium bioaccumulation factor (Table 5).

\section{Lithium uptake by maize}

Lithium uptake was dependent on the analysed part of the plant and on the concentration in the nutrient solution (Table 6). Maize above-ground parts, depending on the concentration in solution, took up from 1.07 to 16.62 -fold more lithium than roots. When analysing the topography of lithium uptake, it was established that the stems took up the largest amount of lithium, followed by roots, and leaves, whereas inflorescences took up the smallest amount.

The lowest lithium uptake was observed at the smallest concentrations in solution of this element in the nutrient solution (1 $\mathrm{mg} \mathrm{Li} \cdot \mathrm{dm}^{-3}$, object 2$)$. Increasing lithium concentrations in solution increased its uptake. The maximum uptake by stems was observed at lithium concentration of $64 \mathrm{mg} \cdot \mathrm{dm}^{-3}$ (D8). The roots had a lower uptake as compared with the stems, taking up the largest amount of this element at a concentration of $16 \mathrm{mg} \mathrm{Li} \cdot \mathrm{dm}^{-3}$ (D6). The uptake was lower in the leaves than in the stems and roots. The highest uptake by leaves was observed at a concentration in solution of $128 \mathrm{mg} \mathrm{Li} \cdot \mathrm{dm}^{-3}$ in the nutrient solution. The inflorescences took up the largest amount of lithium at concentration of
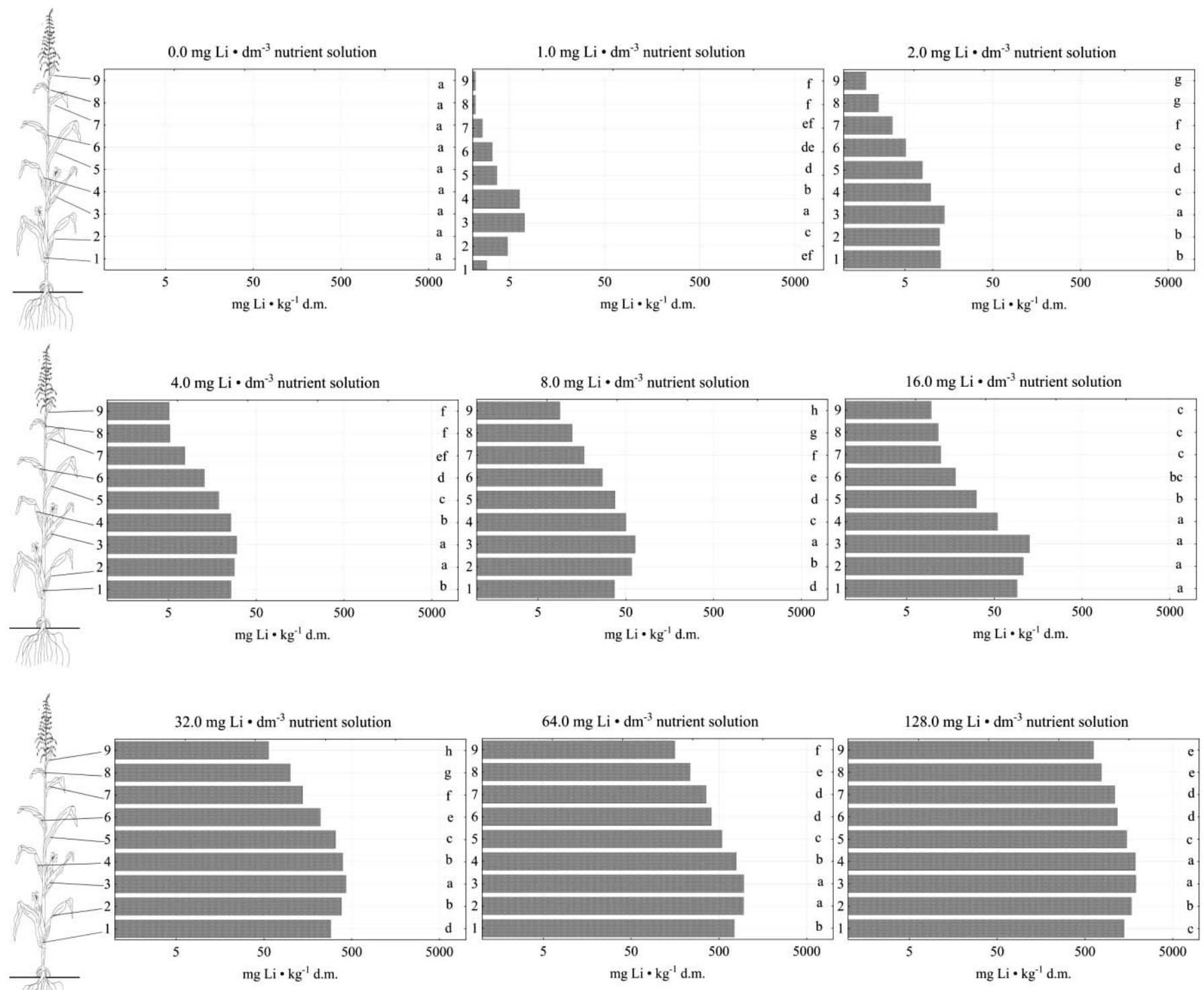

Fig. 1. Lithium concentration in individual layers of maize leaves Zea mays $L$. $\left(\mathrm{mg} \cdot \mathrm{kg}^{-1} \mathrm{~d} . \mathrm{m}\right.$.) 
$64 \mathrm{mg} \mathrm{Li} \cdot \mathrm{dm}^{-3}$ in the nutrient solution (D8). It was impossible to predict the tendency of $\mathrm{Li}$ uptake by inflorescences at concentrations in solution of 128 and $256 \mathrm{mg} \mathrm{Li} \cdot \mathrm{dm}^{-3}$, since inflorescences in these objects did not develop (Table 2).

At the highest lithium concentration in the nutrient solution (256 $\left.\mathrm{mg} \mathrm{Li} \cdot \mathrm{dm}^{-3}, \mathrm{D} 10\right)$, the increase in the uptake of this element in stems, leaves and roots amounted to, respectively, over 38, 88 and 6-fold more compared to the lowest lithium concentration in nutrient solution (D2; Table 6).

When analysed the percentage share of lithium uptake by the index parts of maize, it was established that the stems had the highest share in the uptake of this element, ranging (depending on object) from 38.1 to $73.7 \%$ in relation to total uptake (Table 6). A considerable share in the uptake was

Table 5. The values of lithium translocation factor (TF) and bioaccumulation factor (BAF) in maize Zea mays $L$.

\begin{tabular}{|l|c|c|c|c|c|}
\hline \multirow{2}{*}{ Doses } & \multicolumn{4}{|c|}{ TF } & \multirow{2}{*}{ BAF } \\
\cline { 2 - 5 } & Stems & Leaves & Inflorescences & Above ground parts total & - \\
\hline D1 & - & - & - & - & $11.42 \mathrm{e}$ \\
\hline D2 & $0.08 \mathrm{f}^{\star}$ & $0.06 \mathrm{~d}$ & $0.00 \mathrm{e}$ & $0.08 \mathrm{e}$ & $12.87 \mathrm{c}$ \\
\hline D4 & $0.11 \mathrm{ef}$ & $0.07 \mathrm{~d}$ & $0.00 \mathrm{e}$ & $0.10 \mathrm{e}$ & $13.22 \mathrm{c}$ \\
\hline D5 & $0.10 \mathrm{ef}$ & $0.07 \mathrm{~d}$ & $0.00 \mathrm{e}$ & $0.09 \mathrm{e}$ & $14.42 \mathrm{~b}$ \\
\hline D6 & $0.14 \mathrm{e}$ & $0.08 \mathrm{~d}$ & $0.01 \mathrm{c}$ & $0.12 \mathrm{e}$ & $12.21 \mathrm{~d}$ \\
\hline D7 & $0.09 \mathrm{ef}$ & $0.09 \mathrm{~d}$ & $0.00 \mathrm{~d}$ & $0.09 \mathrm{e}$ & $13.23 \mathrm{c}$ \\
\hline D8 & $0.21 \mathrm{~d}$ & $0.24 \mathrm{c}$ & $0.02 \mathrm{~b}$ & $0.21 \mathrm{~d}$ & $14.93 \mathrm{~b}$ \\
\hline D9 & $0.47 \mathrm{c}$ & $0.44 \mathrm{~b}$ & $0.05 \mathrm{a}$ & $0.46 \mathrm{c}$ & $15.69 \mathrm{a}$ \\
\hline D10 & $0.96 \mathrm{~b}$ & $0.81 \mathrm{a}$ & & $0.91 \mathrm{~b}$ & $9.96 \mathrm{f}$ \\
\hline
\end{tabular}

${ }^{*}$ Means followed by the same letters in columns did not differ significantly at $p<0.05$ according to the Duncan test

Table 6. Uptake (mg Li.growing container ${ }^{-1}$ ) and percentage share of lithium uptake by the indicative parts of maize Zea mays $L$. respect to the total lithium uptake by maize Zea mays $L$.

\begin{tabular}{|c|c|c|c|c|c|c|}
\hline \multirow{2}{*}{ Doses } & \multicolumn{5}{|c|}{ Indicative plant parts } & \multirow{2}{*}{ Total } \\
\hline & Stems & Leaves & Inflorescences & Above ground parts total & Roots & \\
\hline \multirow{2}{*}{ D1 } & $0.00^{*} \mathrm{f}^{*}$ & $0.00 \mathrm{f}$ & $0.00 \mathrm{~d}$ & $0.00 \mathrm{f}$ & $0.00 \mathrm{~h}$ & $0.00 \mathrm{~h}$ \\
\hline & $0.0^{* * *} \mathrm{a}$ & $0.0 \mathrm{a}$ & $0.0 \mathrm{a}$ & $0.0 \mathrm{a}$ & $0.0 \mathrm{a}$ & 100 \\
\hline \multirow{2}{*}{ D2 } & $2.29 \mathrm{f}$ & $0.53 \mathrm{f}$ & $0.00 \mathrm{~d}$ & $2.8 \mathrm{f}$ & $2.0 \mathrm{gh}$ & $4.9 \mathrm{gh}$ \\
\hline & $47.3 \mathrm{c}$ & $11.0 \mathrm{~b}$ & $0.0 \mathrm{a}$ & $58.2 \mathrm{c}$ & $41.8 \mathrm{~g}$ & 100 \\
\hline \multirow{2}{*}{ D3 } & $5.9 \mathrm{f}$ & $1.15 \mathrm{f}$ & $0.00 \mathrm{~d}$ & $7.1 \mathrm{f}$ & $3.8 \mathrm{~g}$ & $11.0 \mathrm{gh}$ \\
\hline & $54.2 \mathrm{~d}$ & $10.5 \mathrm{~b}$ & $0.0 \mathrm{a}$ & $64.7 \mathrm{~d}$ & $35.3 \mathrm{f}$ & 100 \\
\hline \multirow{2}{*}{ D4 } & $12.0 \mathrm{f}$ & $2.57 \mathrm{f}$ & $0.00 \mathrm{~d}$ & $14.5 \mathrm{f}$ & $7.6 \mathrm{f}$ & $22.1 \mathrm{~g}$ \\
\hline & $54.0 \mathrm{~d}$ & $11.6 \mathrm{~b}$ & $0.0 \mathrm{a}$ & $65.6 \mathrm{~d}$ & $34.4 \mathrm{f}$ & 100 \\
\hline \multirow{2}{*}{ D5 } & $29.3 \mathrm{e}$ & $5.17 \mathrm{f}$ & $0.03 \mathrm{c}$ & $34.5 \mathrm{e}$ & $13.5 \mathrm{e}$ & $48.0 \mathrm{f}$ \\
\hline & $61.0 \mathrm{e}$ & $10.8 \mathrm{~b}$ & $0.17 \mathrm{c}$ & $71.9 \mathrm{e}$ & $28.1 \mathrm{e}$ & 100 \\
\hline \multirow{2}{*}{ D6 } & $36 \mathrm{e}$ & $13 e$ & $0.04 \mathrm{c}$ & $49 \mathrm{e}$ & $45.2 \mathrm{a}$ & $93.9 \mathrm{e}$ \\
\hline & $38.1 \mathrm{~b}$ & $13.7 \mathrm{bc}$ & $0.05 \mathrm{~b}$ & $51.9 \mathrm{~b}$ & $48.1 \mathrm{~h}$ & 100 \\
\hline \multirow{2}{*}{ D7 } & $119 \mathrm{c}$ & $39 \mathrm{~d}$ & $0.33 b$ & $158 \mathrm{c}$ & $37.1 \mathrm{~b}$ & $195 \mathrm{c}$ \\
\hline & $61 \mathrm{e}$ & $19.9 \mathrm{~d}$ & $0.17 \mathrm{~d}$ & $80.9 \mathrm{f}$ & $19.1 \mathrm{~d}$ & 100 \\
\hline \multirow{2}{*}{ D8 } & 266 a & $61 \mathrm{~b}$ & $0.81 \mathrm{a}$ & $328 a$ & $33.3 \mathrm{c}$ & $361 \mathrm{a}$ \\
\hline & $73.7 \mathrm{~g}$ & $16.9 \mathrm{~cd}$ & $0.22 \mathrm{e}$ & $90.8 \mathrm{~g}$ & $9.2 \mathrm{c}$ & 100 \\
\hline \multirow{2}{*}{ D9 } & $207 \mathrm{~b}$ & $78 \mathrm{a}$ & & $285 b$ & $17.1 \mathrm{~d}$ & $302 \mathrm{~b}$ \\
\hline & $68.4 \mathrm{f}$ & $25.9 \mathrm{e}$ & & $94.3 \mathrm{~h}$ & $5.7 \mathrm{~b}$ & 100 \\
\hline \multirow{2}{*}{ D10 } & $88 \mathrm{~d}$ & $47 \mathrm{c}$ & & $135 d$ & $12.9 \mathrm{e}$ & $148 d$ \\
\hline & $59.7 \mathrm{e}$ & $31.6 \mathrm{f}$ & & $91.3 \mathrm{~g}$ & $8.7 \mathrm{c}$ & 100 \\
\hline
\end{tabular}

* Lithium uptake by maize $\left(\mathrm{mg} \mathrm{Li} \cdot\right.$ growing container $\left.^{-1}\right)$

** Means followed by the same letters in columns did not differ significantly at $p<0.05$ according to the Duncan test

${ }^{* * *}$ Percentage share of lithium uptake by maize respect to the total lithium uptake (\%) 
observed in the case of roots. The share of roots, depending on object, varied from 5.7 to $48.1 \%$ in relation to total uptake. The percentage share of leaves in lithium uptake, depending on concentration in solution, varied from 10.5 to $31.6 \%$. The lowest percentage share in the uptake was recorded for inflorescences, ranging (depending on concentration in solution) from 0.17 to $0.22 \%$ of the total uptake (Table 6 ).

\section{Lithium utilization factor by maize}

Lithium use by maize (the above-ground parts and roots), depending on amounts in solution, varied from 2.31 to $24.36 \%$ in relation to the amount introduced to the object (Table 7). Increasing lithium concentrations in solution in the growing containers, from 25 to $1,600 \mathrm{mg} \mathrm{Li} \cdot$ growing container ${ }^{-1}$ (D2-D8) caused a significant increase in use of lithium when compared to the control. The highest utilization of lithium was observed at concentration in solution 7, in which $800 \mathrm{mg} \mathrm{Li}$. growing container ${ }^{-1}$ was added (amounting to more than 24\% in relation to lithium amount introduced to that object). The research showed that the lowest values of utilization factor were recorded at concentrations where the highest amount of lithium (3,200-6,400 mg Li · growing container $\left.{ }^{-1}\right)$ was applied, which was surely associated with large concentration of lithium in solution as well as with low yielding and uptake of this element by maize.

\section{Discussion}

This paper attempted to show potentially beneficial effect of lithium on maize, and also to indicate the negative effect of this metal on plants and symptoms of physiological impairments caused by its excess.

\section{The symptoms of physiological diseases}

As mentioned in the Introduction, high lithium concentrations in plant medium can be toxic to plants. At a concentration of 50-100 $\mu \mathrm{g} \cdot \mathrm{l}^{-1}$ in waters used for field irrigation, lithium may have an adverse effect on plants (Kabata-Pendias and Mukherjee 2007). Our research showed that the symptoms of the toxic effect of lithium on the above-ground parts of maize included chloroses, necroses, and browning present at the highest concentrations, namely 128.0 and $256.0 \mathrm{mg} \mathrm{Li} \cdot \mathrm{dm}^{-3}$ of the nutrient solution.

In the results of research carried out by Jurkowska et al. (1998) symptoms of lithium toxic effect on maize cultivated under pot experiment conditions were found in concentrations of $40 \mathrm{mg} \mathrm{Li} \cdot \mathrm{kg}^{-1}$ d.m. in soil.

The research conducted by Hawrylak-Nowak et al. (2012) showed that a solution of lithium of $50 \mathrm{mg} \cdot \mathrm{dm}^{-3}$ causes necrotic changes on sunflower leaves. Citrus plants irrigated with water with lithium compounds had necroses along leaf edges, interveinal leaf chlorosis, and leaf abscission (Bingham et al. 1964). An elevated concentration of lithium in solution (50 mM LiCl) caused necrosis of tobacco leaves (Naranjo et al. 2003). Hence, maize seems to be the plant revealing lithium toxicity symptoms at relatively high concentrations in solution, which implies potential toxicity if green parts of plants contaminated with lithium were used as the feedstuff.

\section{The yield and tolerance index}

In our research, an increase in lithium concentration in the nutrient solution ranging from 1 to $32 \mathrm{Li} \cdot \mathrm{dm}^{-3}$ of the nutrient solution had a stimulating effect on maize yield. Research conducted by Hawrylak-Nowak et al. (2012) also showed that lithium concentration of $25 \mathrm{mg} \cdot \mathrm{dm}^{-3}$ increased maize yield. Research conducted by McStay et al. (1980) also showed that small concentration of lithium $\left(4 \mathrm{mg} \cdot \mathrm{dm}^{-3}\right)$ stimulated the growth of bean (Phaseolus vulgaris). Lithium concentration of more than $4 \mathrm{mg} \cdot \mathrm{dm}^{-3}$ led to closing of the stoma and to disturbance of the water management of bean.

In our experiment, the inhibitory effect of lithium on maize yield was recorded at concentrations of 64, 128 and $256 \mathrm{mg}$ $\mathrm{Li} \cdot \mathrm{dm}^{-3}$ of the nutrient solution. The research conducted by Jurkowska et. al (1998) showed that the doses of lithium $25 \mathrm{mg}$ $\mathrm{Li} \cdot \mathrm{kg}^{-1} \mathrm{~d}$.m. soil in the case of oats and $40 \mathrm{Li} \cdot \mathrm{kg}^{-1} \mathrm{~d}$.m. soil in the case of maize caused a decrease in yields of these plants. The research conducted by Hawrylak-Nowak et al. (2012) confirms that lithium concentration in solution of $50 \mathrm{mg} \cdot \mathrm{dm}^{-3}$ is so unfavourable that it causes depression in maize yielding. It also indicates that maize is a plant more resistant to high lithium

Table 7. Utilization of lithium by maize Zea mays $L$. (\% share of lithium amount taken up by the plant in the total supplied amount of this element)

\begin{tabular}{|l|c|c|c|c|c|c|}
\hline \multirow{2}{*}{ Doses } & \multicolumn{5}{|c|}{ Utilization of lithium by indicative maize parts } & \multirow{2}{*}{ Total } \\
\cline { 2 - 7 } & Stems & Leaves & Inflorescences & Above ground parts & Roots \\
\hline D1 & $0.00 \mathrm{a}^{*}$ & $0.00 \mathrm{a}$ & $0.00 \mathrm{a}$ & $0.00 \mathrm{a}$ & $0.00 \mathrm{a}$ & $0.00 \mathrm{a}$ \\
\hline D2 & $9.17 \mathrm{c}$ & $2.13 \mathrm{~b}$ & $0.00 \mathrm{a}$ & $11.30 \mathrm{c}$ & $8.11 \mathrm{e}$ & $19.41 \mathrm{c}$ \\
\hline D3 & $11.88 \mathrm{~d}$ & $2.30 \mathrm{~b}$ & $0.00 \mathrm{a}$ & $14.17 \mathrm{~d}$ & $7.74 \mathrm{e}$ & $21.91 \mathrm{~d}$ \\
\hline D4 & $11.96 \mathrm{~d}$ & $2.57 \mathrm{bc}$ & $0.00 \mathrm{a}$ & $14.52 \mathrm{~d}$ & $7.62 \mathrm{e}$ & $22.14 \mathrm{~d}$ \\
\hline D5 & $14.63 \mathrm{e}$ & $2.58 \mathrm{bc}$ & $0.02 \mathrm{c}$ & $17.23 \mathrm{e}$ & $6.75 \mathrm{~d}$ & $23.98 \mathrm{de}$ \\
\hline D6 & $8.95 \mathrm{c}$ & $3.22 \mathrm{~cd}$ & $0.01 \mathrm{~b}$ & $12.18 \mathrm{c}$ & $11.29 \mathrm{f}$ & $23.47 \mathrm{de}$ \\
\hline D7 & $14.82 \mathrm{e}$ & $4.85 \mathrm{e}$ & $0.04 \mathrm{~d}$ & $19.72 \mathrm{f}$ & $4.64 \mathrm{c}$ & $24.36 \mathrm{e}$ \\
\hline D8 & $16.64 \mathrm{f}$ & $3.81 \mathrm{~d}$ & $0.05 \mathrm{e}$ & $20.50 \mathrm{f}$ & $2.08 \mathrm{~b}$ & $22.58 \mathrm{de}$ \\
\hline D9 & $6.45 \mathrm{~b}$ & $2.45 \mathrm{~b}$ & & $8.90 \mathrm{~b}$ & $0.54 \mathrm{a}$ & $9.44 \mathrm{~b}$ \\
\hline D10 & $1.38 \mathrm{a}$ & $0.73 \mathrm{a}$ & & $2.11 \mathrm{a}$ & $0.20 \mathrm{a}$ & $2.31 \mathrm{a}$ \\
\hline
\end{tabular}

\footnotetext{
* Means followed by the same letters in columns did not differ significantly at $p<0.05$ according to the Duncan test
} 
concentration in the nutrient solution than sunflower. The higher resistance of maize to lithium can be explained by a faster rate of plant growth, hence the fast biomass increment, and substantial resistance to heavy and light metals (Antonkiewicz and Para 2016, Rizwan et al. 2016). Arabidopsis thaliana, which belongs to the family of Brassicaceae, exhibited high resistance to high lithium concentration of more than $70 \mathrm{mg}$. $\mathrm{dm}^{-3}$ (An et al. 2007), whereas lower lithium concentration of 35 $\mathrm{mg} \cdot \mathrm{dm}^{-3}$ stimulated the increase in elongation of Arabidopsis thaliana L. roots. Other authors ( $\mathrm{Li}$ et al. 2009) have shown that concentration of up to $30 \mathrm{mM} \mathrm{LiCl}$ has almost no effect on germination and increase of parameters of plants belonging to the family of Brassicaceae (Brassica carinata). However, if that concentration is exceeded, toxicity of this metal increases quickly and affects plant germination and yield.

\section{Lithium concentration}

In our research, attention was paid to the process of uptake and transfer of lithium under conditions of abiotic stress caused by different lithium concentration in nutrient solution. It was established that maize roots accumulated more lithium than the above-ground parts. The lowest concentrations of lithium were found in maize inflorescences. Basically, inflorescences produced at relatively low concentration of lithium in solution (0-4 mg $\cdot \mathrm{dm}^{-3}$ of the nutrient solution) did not take up this element. Our results support the results of research by Kabata-Pendias and Mukherjee (2007) who have shown that lithium (as a metallic element) is not required for the plant flowering process, therefore it does not have to be taken up from the substratum.

The research conducted by Bingham et al. (1964) showed that maize is the species more resistant to lithium and can accumulate higher amounts of this element than tomatoes, grapes and kidney bean. The results of research carried out by Hawrylak-Nowak et al. (2012) revealed that the above-ground parts of maize accumulate much lower amounts of lithium than the above-ground parts of sunflower, which is also associated with varying species resistance to lithium compounds (Kalinowska et al. 2013). Other studies have shown that lithium compounds can substitute potassium or sodium which are taken up by plants, including sodium-loving plants (An et al. 2007, Aral and Vecchio-Sadus 2008, Yalamanchali 2012).

\section{Translocation and bioaccumulation factors}

Our research showed that increasing values of translocation and bioaccumulation factors in maize are indicative of intensive translocation of lithium in the nutrient solution to the above-ground parts. In all probability, translocation and bioaccumulation of lithium in the plant resulted from a high concentration of this element in the nutrient solution (Lintschinger et al. 1997, Małachowska-Jutsz and Gnida 2015). Kabata-Pendias and Mukherjee (2007) also state that lithium is transported in plants similarly to potassium, therefore it is easily transferred to the above-ground parts and accumulated mainly in plant leaves. The obtained results of our research point also to retention of this element in the roots, which is of considerable importance in defence processes against phytotoxicity of this element (Aral and Vecchio-Sadus 2008).

\section{Lithium uptake}

As in the case of other nutrients, the amount of lithium taken up by plants depends on abiotic and biotic factors (Naranjo et al. 2003, Mackay and Fraser 2010). Some of important factors which influence the uptake of lithium and other metals are the plant species, genotype, and also the structure of roots (Zonia and Tupy 1995, Lu et al. 2010, Antonkiewicz et al. 2016, Borowiak et al. 2016). Our research showed higher uptake of lithium by the above-ground parts of maize than by the roots, which primarily resulted from higher yield of these parts of the plant. This confirms the results of research carried out by Hawrylak-Nowak et al. (2012) and supports the idea of using maize for lithium rhizofiltration of contaminated water or possibly soil remediation by phytoextraction.

\section{Lithium utilization}

Similarly to potassium, lithium (being a mobile element) is easily taken up by plants and accumulated in them in large amounts (Kabata-Pendias and Mukherje 2007). On account of its substantial mobility, lithium can be recovered from waters and soil by selected plant species, including Brassica carinata ( $\mathrm{Li}$ et al. 2009). Our research showed that maize, depending on lithium amount in the nutrient solution, utilized between 2 and $24 \%$ of the amount of this element introduced into the growing container. Such high utilization of lithium by maize can be explained by substantial yielding and uptake of this metal by maize, binding, detoxification, which finds confirmation in other studies (Antonkiewicz and Para 2016, Hawrylak-Nowak et al. 2012, Rizwan et al. 2016). However, one must remember that the properties of plants to remediate lithium-contaminated soils depend on the soil type and $\mathrm{pH}$ (Kabata-Pendias and Pendias 1992, Schrauzer 2002, Aral and Vecchio-Sadus 2008). Also an antagonistic interaction between lithium and calcium absorption can occur, hence additional practices such as soil amendment or chelator application, and identification of lithium-tolerant genotypes should be considered (Shahzad et al. 2016). Hence, while planning to use maize for phytoremediation of a specific soil, the research should comprise such considerations.

\section{Conclusions}

1. Phytotoxicity of lithium on maize becomes apparent at concentrations of 64,128 , and $256 \mathrm{mg} \mathrm{Li} \cdot \mathrm{dm}^{-3}$ in the nutrient solution. Generally, the morphological phytotoxic effect of lithium can be highlighted on the leaves (chloroses, necroses, browning) and roots (thickening and shortening of the main root, brown color).

2. Assuming the yield is an indicator of plant response to the presence of lithium in the nutrient solution, it needs to be stated that the concentration in solution ranging from 1 to 64 $\mathrm{mg} \mathrm{Li} \cdot \mathrm{dm}^{-3}$ had a stimulating effect, whereas a depression in yielding occurred only at the concentrations of 128 and $256 \mathrm{mg} \mathrm{Li} \cdot \mathrm{dm}^{-3}$. The values of tolerance index indicate that maize roots were more resistant to the toxic effect of lithium than the above-ground parts.

3. The increase in lithium concentration in the nutrient solution was accompanied by an increase in the concentration of this element in individual index parts of maize, in the order roots $>$ stems $>$ leaves $>$ inflorescences.

4. At the highest lithium concentration in the nutrient solution (256 $\mathrm{mg} \mathrm{Li} \cdot \mathrm{dm}^{-3}$ of the nutrient solution), the values of translocation factor in the above-ground parts and stems were higher than one, which is an indicative 
of an intensive transfer of lithium from the roots to the above-ground parts.

5. Lithium uptake by maize was dependent on the analysed part of the plant and on lithium concentration. The above-ground parts, depending on the concentration in solution, took up from 0.4 to 15.6 -fold more lithium than roots. The stems accumulated the largest amount of lithium, followed by the roots and leaves, whereas the uptake by the inflorescences was the smallest.

6. Lithium use by maize, depending on the amounts of lithium in solution, varied from approx. 2 to $25 \%$ in relation to the amount introduced into the medium. The lowest values of utilization factor were recorded in the objects where the highest amount of lithium (3,200-6,400 mg Li · growing container-1 $^{-1}$ ) was applied, which was surely associated with the large concentrations of lithium as well as with the low yielding and uptake of this element by the plants.

\section{Acknowledgments}

This work was financed by the science fund of the Polish Ministry of Science and Higher Education, as a research project No. 3101 .

\section{References}

Alexander, B., Browse, D.J., Reading, S.J. \& Benjamin, I.S. (1999). A simple and accurate mathematical method for calculation of the EC50, Journal of Pharmacological and Toxicological Methods, 41 (2-3), pp. 55-58. DOI:10.1016/S1056-8719(98)00038-0

Allender, W.J., Cresswell, G.C., Kaldor, J. \& Kennedy, I.R. (1997). Effect of lithium and lanthanum on herbicide induced hormesis in hydroponically-grown cotton and corn, Journal of Plant Nutrition, 20, 1, pp. 81-95. DOI:10.1080/01904169709365235

Al-Thyabat, S., Nakamura, T., Shibata, E. \& Iizuka, A. (2013). Adaptation of minerals processing operations for lithium-ion (LiBs) and nickel metal hydride (NiMH) batteries recycling: critical review, Minerals Engineering, 45, pp. 4-17. DOI:10.1016/j.mineng.2012.12.005

An, R., Chen, Q.J., Chai, M.F., Lu, P.L., Su, Z., Qin, Z.X., Chen, J. \& Wang, X.C. (2007). AtNHX8, a member of the monovalent cation:proton antiporter-1 family in Arabidopsis thaliana, encodes a putative $\mathrm{Li}^{+} / \mathrm{H}^{+}$antiporter, The Plant Journal, 49, 4, pp. 718-728. DOI:10.1111/j.1365-313X.2006.02990.x

Antonkiewicz, J. \& Para, A. (2016). The use of dialdehyde starch derivatives in the phytoremediation of soils contaminated with heavy metals, International Journal of Phytoremediation, 18, 3, pp. 245-250. DOI:10.1080/15226514.2015.1078771

Antonkiewicz, J., Jasiewicz, C., Koncewicz-Baran, M. \& Sendor, R. 2016. Nickel bioaccumulation by the chosen plant species. Acta Physiologiae Plantarum, 38, 40, pp. 11. DOI:10.1007/s11738016-2062-5

Aral, H. \& Vecchio-Sadus, A. (2008). Toxicity of lithium to humans and the environment - a literature review, Ecotoxicology and Environmental Safety, 70, 3, pp. 349-356. DOI:10.1016/j. ecoenv.2008.02.026.

Audet, P. \& Charest, C. (2007). Heavy metal phytoremediation from a meta-analytical perspective, Environmental Pollution, 147, pp. 231-237. DOI:10.1016/j.envpol.2006.08.011.

Bingham, F.T., Bradford, G.R. \& Page, A.L. (1964). Toxicity of lithium to plants, California Agriculture, 18, 9, pp. 6-7.

Borowiak, K., Kanclerz, J., Mleczek, M., Lisiak, M. \& Drzewiecka, K. (2016). Accumulation of $\mathrm{Cd}$ and $\mathrm{Pb}$ in water, sediment and two litoral plants (Phragmites australis, Typha angustifolia) of freshwater ecosystem. Archives of Environmental Protection, 42, 3, pp. 47-57. DOI:10.1515/aep-2016-0032.

Bradford, G.R. (1963). Lithium California's water resources, California Agriculture, 17, 5, pp. 6-8.

Calabrese, E.J. \& Baldwin, L.A. (2003). Hormesis: The dose-response revolution, Annual Reviews of Pharmacology and Toxicology, 43, pp. 175-197. DOI:0.1146/annurev.pharmtox.43.100901.140223

Enghag, P. (2008). Encyclopedia of the Elements: Technical Data-history-processing applications, Wiley-VCH, Weinheim 2008.

Forbes, V.E. (2000). Is hormesis an evolutionary expectation? Functional Ecology, 14, 1, pp. 14-24. DOI:10.1046/j.13652435.2000.00392.x

Franzaring, J., Schlosser, S., Damsohn, W. \& Fangmeier, A. (2016). Regional differences in plant levels and investigations on the phytotoxicity of lithium, Environmental Pollution, 216, pp. 858-865. DOI:10.1016/j.envpol.2016.06.059

Garzon, C.D. \& Flores, F.J. (2013). Hormesis: Biphasic dose-responses to fungicides in plant pathogens and their potential threat to agriculture, Agricultural and Biological Sciences. Fungicides - Showcases of Integrated Plant Disease Management from Around the World. 12, pp. 311-328. DOI:10.5772/55359

Hawrylak-Nowak, B., Kalinowska, M. \& Szymańska, M. (2012). A study on selected physiological parameters of plants grown under lithium supplementation, Biological Trace Element Research, 149, 3, pp. 425-430. DOI:10.1007/s12011-012-9435-4

Hoagland, D.R. \& Arnon, D.I. (1950). The water-culture method for growing plants without soil, California Agriculture Experiment Station Circular, 347, pp. 1-32.

Hull, S.L., Oty, U.V. \& Mayes, W.M. (2014). Rapid recovery of benthic invertebrates downstream of hyperalkaline steel slag discharges, Hydrobiologia, 736, pp. 83-97.

Jurkowska, H. \& Rogóż, A. (1991). Uptake of lithium by plants as depending on soil moisture content, Polish Journal of Soil Science, 24, pp. 93-97.

Jurkowska, H., Rogóż, A. \& Wojciechowicz, T. (1998). Comparison of lithium toxic influence on some cultivars of oats, maize and spinach, Acta Agraria et Silvestria. Series Agraria, 36, pp. 37-42. (in Polish)

Jurkowska, H., Rogóż, H. \& Wojciechowicz, T. (2003). Phytotoxicity of lithium on various soils, Polish Journal of Soil Science, 36, 1, pp. 71-76.

Kabata-Pendias, A. \& Pendias, H. (1992). Trace Elements in Soils and Plants, second ed. CRC Press, Boca Raton, London 1992.

Kabata-Pendias, A. \& Pendias, H. (1999). Biogeochemistry of trace elements, Wyd. Nauk. PWN, Warsaw 1999. (in Polish)

Kabata-Pendias, A. \& Mukherjee, A.B. (2007). Trace elements from soil to human, Springer-Verlag Berlin Heidelberg 2007.

Kalinowska, M., Hawrylak-Nowak, B. \& Szymańska, B. (2013). The influence of two lithium forms on the growth, L-Ascorbic acid content and lithium accumulation in lettuce plants, Biological Trace Element Research, 152, 2, pp. 251-257. DOI:10.1007/ s12011-013-9606-y

Kayihan, C., Eyidogan, F., Afsar, N., Oktem, H.A. \& Yucel, M. (2012). $\mathrm{Cu} / \mathrm{Zn}$ superoxide dismutase activity and respective gene expression during cold acclimation and freezing stress in barley cultivars, Biologia Plantarum, 56, 4, pp. 693-698. DOI:10.1007/ s10535-012-0143-x

Kusznierewicz, B., Bączek-Kwinta, R., Bartoszek, A., Piekarska, A., Huk, A., Manikowska, A., Antonkiewicz, J., Namieśnik, J. \& Konieczka, P. (2012). The dose-dependent influence of zinc and cadmium contamination of soil on their uptake and glucosinolate content in white cabbage (Brassica Oleracea var. Capitata F. Alba), Environmental Toxicology and Chemistry, 31, 11, pp. 2482-2489. DOI:10.1002/etc. 1977

Léonard, A., Hantson, Ph. \& Gerber, G.B. (1995). Mutagenicity, carcinogenicity and teratogenicity of lithium compounds, 
Mutation Research, 339, 3, pp. 131-137. DOI:10.1016/01651110(95)90007-1

Li, X., Gao, P., Gjetvaj, B.,Westcott, N. \& Gruber, M.Y. (2009). Analysis of the metabolome and transcriptome of Brassica carinata seedlings after lithium chloride exposure, Plant Science, 177, 1, pp. 68-80. DOI:10.1016/j.plantsci.2009.03.013

Lintschinger, J., Fuchs, N., Moser, H., Jäger, R., Hlebeina, T., Markolin, G. \& Gössler, W. (1997). Uptake of various trace elements during germination of wheat, buckwheat and quinoa, Plant Foods for Human Nutrition, 50, 3, pp. 223-237. DOI: $10.1007 / \mathrm{BF} 02436059$

Lu, Y., Li, X., He, M., Zhao, X., Liu, Y., Cui ,Y., Pan, Y. \& Tan, H. (2010). Seedlings growth and antioxidative enzymes activities in leaves under heavy metal stress differ between two desert plants: a perennial (Peganum harmala) and an annual (Halogeton glomeratus) grass, Acta Physiologiae Plantarum, 32, pp. 583-590. DOI:10.1007/s11738-009-0436-7

Mackay, D. \& Fraser, A. (2000). Bioaccumulation of persistent organic chemicals: mechanisms and models, Environmental Pollution, 110, pp. 375-391. DOI:S0269-7491(00)00162-7

Małachowska-Jutsz, A. \& Gnida, A. (2015). Mechanisms of stress avoidance and tolerance by plants used in phytoremediation of heavy metals. Archives of Environmental Protection, 41, 4, pp. 104-114. DOI:10.1515/aep-2015-0045

Marchiol, L., Sacco, P., Assolari, S. \& Zerbi, G. (2004). Reclamation of polluted soil: phytoremediation potential of crop-related Brassica Species, Water, Air and Soil Pollution, 158, pp. 345-356. DOI:10.1023/B:WATE.0000044862.51031.fb

McStay, N.G., Rogers, H.H. \& Anderson, C.E. (1980). Effects of lithium on Phaseolus vulgaris L., Science of the Total Environment, 16, 2, pp. 185-191. DOI:10.1016/0048-9697(80)90023-6

Murphy, A. \& Tayz, L. (1995). A new vertical mesh transfer technique for metal-tolerance studies in Arabidopsis (ecotypic variation and copper-sensitive mutants), Plant Physiology, 108, pp. 29-38. DOI:10.1104/pp.108.1.29

Naranjo, M.A., Romero, C., Bellés, J.M., Montesinos, C., Vicente, O. \& Serrano, R. (2003). Lithium treatment induces a hypersensitive-like response in tobacco, Planta, 217, 3, pp. 417-424. DOI:10.1007/s00425-003-1017-4
Ostrowska, A., Gawliński, S. \& Szczubiałka, Z. (1991). Methods of analysis and assessment of soil and plant properties. A Catalogue, Institute of Environmental Protection - National Research Institute, Warsaw 1991.

Rizwan, M., Ali, S., Qayyum, M.F., Ok, Y.S., Zia-ur-Rehman, M., Abbas, Z. \& Hannan, F. (2016). Use of maize (Zea mays L.) for phytomanagement of Cd-contaminated soils: a critical review, Environmental Geochemistry and Health, 39(2), pp. 259-277. DOI: 10.1007/s10653-016-9826-0

Ruus, A., Schaanning, M., Øxnevad, S. \& Hylland, K. (2005). Experimental results on bioaccumulation of metals and organic contaminants from marine sediments, Aquatic Toxicology, 72(3), pp. 273-292. DOI:10.1016/j.aquatox.2005.01.004

Schrauzer, G.N. (2002). Lithium: Occurrence, Dietary Intakes, Nutritional Essentiality, Journal of American College Nutrition, 21, pp. 14-21.

Shacklette, H.T. \& Boerngen, J.G. (1984). Element. Concentration in Soils and Other Surficial Materials of the Conterminous United States, Geological Survey Professional Paper, p. 1270, United States Government Printing Office, Washington 1984.

Shahzad, B., Mohsin, T., Waseem, H., Shah, A.N., Shakeel, A.A., Cheema, S.A. \& Iftikhar, A. (2016). Lithium toxicity in plants: Reasons, mechanisms and remediation possibilities - A review, Plant Physiology and Biochemistry, 107, pp. 104-115.

Szentmihalyi, S., Siegert, E., Hennig, A., Anke, M. \& Groppel, B. (1985). Zinc contents of flora in relation to age. geology of soil and plant species. Proc. Macro- and Trace Element. Seminar, University Leipzig-Jena, Germany 1985.

Zonia, L.E. \& Tupy, J. (1995). Lithium-sensitive calcium activity in the germination of apple (Malus $\times$ domestica Borkh.), tobacco (Nicotiana tabacum L.), and potato (Solanum tuberosum L.) pollen, Journal of Experimental Botany, 46, 8, pp. 973-979. DOI: $10.1093 / \mathrm{jxb} / 46.8 .973$

Yalamanchali, R.C. (2012). Lithium, an emerging environmental contaminant, is mobile in the soil-plant system, A thesis submitted in partial fulfillment of the requirements for the Degree of Master of Applied Science At Lincoln University. Lincoln University. Lincoln 2012.

\title{
Określenie bioretencji litu przez kukurydzę w warunkach kultur hydroponicznych
}

\begin{abstract}
Streszcznie: Celem badań było określenie zdolności kukurydzy do bioakumulacji litu. Badania prowadzono w warunkach kultur wodnych. Schemat doświadczenia obejmował 10 obiektów różniących się stężeniem litu w roztworze wodnym, w zakresie od $0.0-256.0 \mathrm{mg} \mathrm{Li} \cdot \mathrm{dm}^{-3}$ pożywki. Jako parametry, na postawie których określono bioretencję litu przez kukurydzę przyjęto: plon, zawartość litu w różnych częściach rośliny, pobranie i wykorzystanie tego pierwiastka oraz indeksy: tolerancji plonu (TI), translokacji (TF), stężenia metalu w częściach nadziemnych (CI) i bioakumulacji (BAF). Depresja plonowania kukurydzy wystąpiła przy dawce 128 i $256 \mathrm{mg}$ $\mathrm{Li} \cdot \mathrm{dm}^{-3}$. Na podstawie uzyskanych wyników stwierdzono, że korzenie charakteryzowały się największymi zawartościami litu, natomiast niższymi łodygi i liście, a najmniejszymi kwiatostany. Wartości indeksu translokacji świadczą o intensywnym przemieszczaniu się litu z korzeni do części nadziemnych. Najwięcej litu pobrały łodygi, następnie korzenie, liście, a najmniej kwiatostan. Pobranie litu przez kukurydzę, w zależności od obiektu, wahało się od 2.31 do $24.36 \%$ w stosunku do ilości wprowadzonej do obiektu. Najmniejszy fitoodzysk odnotowano w obiektach, w których zastosowano największe ilości litu (3200-6400 mg Li $\cdot$ akwarium ${ }^{-1}$ ), co zapewne było związane z dużymi dawkami litu oraz niskim plonowaniem i pobraniem tego pierwiastka przez kukurydzę.
\end{abstract}

